\title{
Health risk assessment resulting from the presence of Legionella bacteria in domestic hot water in public buildings - the results of a pilot study
}

\author{
Ewa Kmiecik ${ }^{1}$, Katarzyna Wątor ${ }^{2}$, Aneta Chochorek ${ }^{3}$, Mateusz Kołodziej ${ }^{4}$, \\ Anna Mika ${ }^{5}$, Arkadiusz Krawiec ${ }^{6}$, Janusz Herzig ${ }^{7}$ \\ ${ }^{1}$ AGH University of Science and Technology, Faculty of Geology, Geophysics and Environment Protection; Krakow, Poland; \\ e-mail:ewa.kmiecik@agh.edu.pl; ORCID ID:0000-0003-3249-4642 \\ ${ }^{2}$ AGH University of Science and Technology, Faculty of Geology, Geophysics and Environment Protection; Krakow, Poland; \\ e-mail: katarzyna.wator@agh.edu.pl (corresponding author); ORCID ID: 0000-0002-1921-5146 \\ ${ }^{3}$ ALS Food \& Pharmaceutical Polska; Krakow, Poland; e-mail: aneta.chochorek@ALSGlobal.com \\ ${ }^{4}$ Galvano-Partners; Łódź, Poland; e-mail: kolodziej.mate@gmail.com \\ ${ }^{5}$ AGH University of Science and Technology, Faculty of Geology, Geophysics and Environment Protection; Krakow, Poland \\ ${ }^{6}$ Nicolaus Copernicus University, Faculty of Earth Sciences and Spatial Management; Torun, Poland; \\ e-mail: arekmrv@umk.pl; ORCID ID:0000-0003-2310-055X \\ ${ }^{7} A G H$ University of Science and Technology, Faculty of Geology, Geophysics and Environment Protection; Krakow, Poland; \\ e-mail: herzig@agh.edu.pl; ORCID ID: 0000-0002-9545-4886
}

(c) 2021 Authors. This is an open access publication, which can be used, distributed and reproduced in any medium according to the Creative Commons CC-BY 4.0 License requiring that the original work has been properly cited.

Received: 1 October 2020; accepted: 27 April 2021; first published online: 6 May 2021

\begin{abstract}
The aim of the study was to assess the risk posed by Legionella bacteria in a public building in Krakow. An old building with internal installation risers of different ages, as well as draw-off points of different types, was selected for testing. Samples were collected during two campaigns. In one sample of the first series of tests, no bacteria were found. During the second series of tests, no Legionella bacilli were found in just one sample and in one sample only 4 colony-forming units were detected. At the remaining draw-off points (water taps), the bacteria count detected were greater than the maximum threshold allowed by legal regulations (admissible threshold for public utility buildings - $100 \mathrm{cfu} / 100 \mathrm{~mL}$ ). No morphological differences were observed with respect to the occurrence of specific serogroups. In 14 samples, Legionella pneumophila serogroups 2-14 were found, while the Legionella pneumophilaserogroup 1 was only found in one sample. The risk assessment was also carried out based on a semi-quantitative risk matrix approach and as a quantitative microbial risk assessment. The risk matrix approach was successfully implemented for the recognition of the potential risk associated with the Legionella occurrence in a water system. The calculated annual cumulative risk is high. The research shows that even if the weekly inhalation exposure dose (and therefore the calculated risk) is high, the number of Legionella pneumophila illness cases found can be equal to zero. This is probably due to the large uncertainty associated with QMRA determination. The size of the room in which the contaminated water is used also affects the possibility of infection.
\end{abstract}

Keywords: Legionella pneumophila, tap water, public building, quantitative microbial risk assessment, risk matrix 


\section{INTRODUCTION}

The first observed cases of the disease caused by Legionella bacteria occurred in 1976 during a congress of the American Legion in Philadelphia, U.S. At that time, as many as 221 people fell ill and 34 died (Garret 1994). Legionella bacilli owe their name to that outbreak, and the disease they cause has been called legionellosis.

Legionella is gram-negative, aerobic rodshaped, motile, and non-spore-forming bacteria (Rasilainen et al. 2005). The number of recognized Legionella species and serogroups is constantly growing. Currently, there are over 60 known species and 80 serogroups. Several Legionella species can cause human diseases such as Legionnaires' disease and Pontiac fever. Legionella pneumophila still causes the most community-acquired infections and nosocomial infections (Helbig et al. 2002, Yu et el. 2002, Amemura-Maekawa et al. 2010, 2018, Miyashita et al. 2020). Eighty to eighty-five percent of infections caused by Legionella have been related to Legionella pneumophila. Serogroups 1 and 6 are responsible for two-thirds of all reported Legionella infections ( $\mathrm{Yu}$ et al. 2002). This is why most detection methods have been developed to identify Legionella pneumophila (Miyashita et al. 2020).

Natural Legionella habitats include freshwater bodies (rivers, streams, lakes), groundwater, geysers, highly eutrophic saline waters, municipal and industrial waterworks, public buildings, soils, sewerage systems, air-conditioning installations and biofilms on the surface of water bodies (Huang et al. 2011, Benhammou et al. 2012, Walczak et al. 2013a, 2013b, 2016, Liguori et al. 2014, Kmiecik et al. 2017, Mika et al. 2019). The transport of Legionella and their introduction into other environments occur by means of air and water spray (aerosols). Such an aerosol is produced by many devices in doctor's offices, at swimming pools, in public spaces (showers, fountains), public toilets, and air-conditioned spaces in which periodic inspections are carried out (US EPA 1999). Human infection only occurs by aerosol inhalation (Rafiee et al. 2014, Walser et al. 2014). Over the last few years, the number of outbreaks has increased strongly (Delgado-Viscogliosi et al. 2005).
The Polish Regulation of the Minister of Infrastructure (Rozporządzenie 2002) includes provisions envisaging the protection of hot water distribution systems in buildings against the growth of Legionella bacteria. According to the Regulation, hot water distribution system should be capable of producing water at water draw-off points with a temperature no less than $55^{\circ} \mathrm{C}$ and no more than $60^{\circ} \mathrm{C}$. Hot water distribution systems should allow continuous or periodical chemical or physical disinfection (including the periodic application of the thermal disinfection method) without reducing the durability of the system and the products it includes. For thermal disinfection purposes, it must be ensured that the water temperature at draw-off points is no less than $70^{\circ} \mathrm{C}$ and not higher than $80^{\circ} \mathrm{C}$. However, this provision only applies to newly designed buildings.

According to European technical guidelines (ESGLI 2017), the pipework and any components should be easy to inspect so that the thermal insulation and temperature monitoring can be checked.

In the Regulation of the Minister of Health (Rozporządzenie 2005), Legionella bacterium is classified as a so-called harmful biological agent. This is the fundamental legal act that governs the protection of employees against harmful biological factors such as Legionella in Poland.

The obligation to test for the presence of $L e$ gionella in domestic hot water was introduced by the Regulation of the Minister of Health (Rozporządzenie 2015a). The latter Regulation established the obligation to test domestic hot water in multi-apartment residential buildings and public buildings for Legionella where air and water spray (aerosol) is generated during use (permissible number of microorganisms: $<100$ in $100 \mathrm{~mL}$ of water). The Regulation also stipulates the recommended method of testing for Legionella sp., which is described in the ISO standard no. 11731:2017 (ISO 2017). Another method may be used as well provided that its equivalence with the aforementioned method is documented.

The revised Drinking Water Directive (Directive 2020) includes a new provision on the risks associated with domestic distribution. Article 10 introduces the obligation to monitor for the 
presence of Legionella when assessing the risk associated with domestic distribution systems. Legionella has been found by the WHO to cause the highest health burden of all waterborne pathogens in the European Union. In addition, it is also recommended by the European Centre for Disease Prevention and Control (ECDC 2017) to apply regular checks and appropriate control measures to man-made water systems as a means to prevent cases of Legionnaires' disease at tourist accommodation sites, hospitals, long-term healthcare facilities or other settings where sizeable populations at higher risk may be exposed (Directive 2020). For the purposes of Articles 10 and 14, the parametric value for Legionella is set as $<1000 \mathrm{cfu} / \mathrm{L}$. Actions provided for in those Articles could be considered even when the value is below the parametric value, e.g., in cases of infections and outbreaks. In such cases, the source of infection should be confirmed and the species of Legionella identified.

Poland is in the group of countries with a relatively low level of incidence. Unfortunately, however, this may result from difficulties in diagnosing this disease correctly. It should be recognized that associated severe pneumonia cases are too rarely associated with Legionella infection, which results in the delayed administration of appropriate therapy and a failure to detect environmental sources of infection (Stypułkowska-Misiurewicz \& Czerwiński 2016).

In this context, the objective of the study was to assess the risk posed by Legionella bacteria in a public building in Krakow. An old building with internal installation risers of different ages, as well as draw-off points of different types, was selected for testing.

\section{MATERIALS AND METHODS}

\section{Sampling points locations}

An experiment was conducted in order to assess the risk posed by Legionella bacteria in a public building in one of the districts of Krakow (Poland, Lesser Poland Voivodeship). An old building with internal installation risers of different ages, as well as draw-off points (taps/showers) of different types (no-touch infrared sensor and classical taps), was selected for testing. Two sampling series named
A and B were made. The first campaign (series A) was performed as a preliminary test to recognize if the problem with Legionella occurred. The locations of sampling points are summarized in Table 1, while their characteristics are presented in Table 2.

Table 1

Water sampling locations and their names

\begin{tabular}{|c|c|c|c|c|c|}
\hline \multirow{2}{*}{$\begin{array}{c}\text { Floor } \\
\text { no. }\end{array}$} & \multicolumn{5}{|c|}{ Water supply riser } \\
\cline { 2 - 6 } & $\mathbf{1}$ & $\mathbf{2}$ & $\mathbf{3}$ & $\mathbf{4}$ & $\mathbf{5}$ \\
\hline-1 & $\mathrm{~A} 1 / \mathrm{B}^{*}{ }_{\mathrm{S}}$ & $\mathrm{B} 2_{\mathrm{S}}$ & $\mathrm{B} 3_{\mathrm{C}}$ & $\mathrm{A} 2_{\mathrm{C}}$ & - \\
\hline 0 & $\mathrm{~B} 4_{\mathrm{S}}$ & $\mathrm{B} 5_{\mathrm{S}}$ & - & $\mathrm{B} 6_{\mathrm{S}}$ & $\mathrm{B} 7_{\mathrm{S}}$ \\
\hline+1 & - & $\mathrm{B} 8_{\mathrm{S}}$ & - & $\mathrm{B} 9_{\mathrm{S}}$ & $\mathrm{B} 10_{\mathrm{S}}$ \\
\hline+2 & $\mathrm{~B} 11_{\mathrm{S}}$ & $\mathrm{B} 12_{\mathrm{S}}$ & - & $\mathrm{B} 13_{\mathrm{S}}$ & $\mathrm{B} 14_{\mathrm{S}}$ \\
\hline+3 & - & - & - & $\mathrm{B} 15_{\mathrm{C}}$ & $\mathrm{A} 3 /{\mathrm{B} 16^{*}}_{\mathrm{C}}$ \\
\hline
\end{tabular}

Sampling series: A and B; types of tap: S - sensory, C - classic, * equivalent points in both test series.

During the first sampling, the following samples were collected: sample A1 - from the shower using a disinfected funnel and samples A2 and A3 - directly from taps (Tab. 1).

During the second sampling, samples were collected from taps in the bathrooms, in different water supply risers. The taps were both no-touch infrared sensor and conventional (classical) ones. During this test stage, 16 water samples were collected (samples B1-B16) (Tab. 1).

\section{Sampling methodology}

The water samples with a volume of $650-750 \mathrm{~mL}$ were collected into sterile $1000 \mathrm{~mL}$ polypropylene bottles which contained sodium thiosulphate in order to fix the sample. The samples were collected aseptically using sterile gloves, observing all safety and hygiene principles related to the samples so as not to contaminate the sample with any substances which could affect the test results. The air left in the bottle $(250 \mathrm{~mL})$ allowed the mixing of water samples and provided microbial organisms with access to oxygen. Thiosulphate (sodium or potassium) is necessary to inactivate disinfectants. Culture method can return false negative results if the bottles used to collect chlorinated tap water samples do not contain a neutralising agent to immediately inactivate residual halogen biocides (Wiedenmann et al. 2001). Directly before the water samples had been collected, the water temperature was measured 
using a calibrated mercury thermometer. The water samples were transported as soon as possible to the accredited Wessling Poland laboratory in Poznań (PCA No. AB918).

\section{Analysis methodology}

Water samples were tested for the presence of $L e$ gionella bacteria within 24 hours of their collection, using the reference method described in the ISO standard no.11731:2017(ISO 2017). The detection/quantification limit for Legionella using this method was $1 \mathrm{cfu} / 100 \mathrm{~mL}$.

Results are given in the form of an estimated number of colony-forming units (cfu) of Legionella bacteria in a $1000 \mathrm{~mL}$ water sample (often as cfu/100 mL).

Additionally, in the samples collected during the second series of tests, serotyping was carried out to distinguish the following strains: Legionella pneumophilaserogroup 1 and serogroups from 2 to 14 and Legionella spp.

\section{Risk analysis methodology}

In the semi-quantitative risk matrix approach, the likelihood $(L)$, frequency $(F)$, and severity of consequence $(S)$ of selected hazard events which can occur in a scale from 1 to 5 were taken into account during the risk $(R)$ assessment. The risk was calculated by multiplying likelihood or frequency by severity. In the presented work, the risk levels were divided into low (a risk score below 10), medium (a risk score between 10 and 19), and high (a risk score above 20) as proposed by other researchers (Papadakis et al. 2018).

\section{RESULTS AND DISCUSSION}

The results of the research are presented in Table 2.

Table 2

Microbiological characterization of the collected samples

\begin{tabular}{|c|c|c|c|c|}
\hline Sample no. & Sampling point type & $\begin{array}{l}\text { Water temperature } \\
\qquad\left[{ }^{\circ} \mathbf{C}\right]\end{array}$ & $\begin{array}{l}\text { Number of bacteria } \\
{[\text { CFU/100 mL] }}\end{array}$ & $\begin{array}{c}\text { Legionella } \\
\text { pneumophila } \\
\text { serogroup }\end{array}$ \\
\hline \multicolumn{5}{|c|}{ Sampling A (Kmiecik et al. 2017) } \\
\hline A1 & S/men's bathroom & 27.0 & $1.6 \times 10^{3}$ & \multirow{3}{*}{ not analysed } \\
\hline A2 & C/shower tap & 24.4 & $1.2 \times 10^{3}$ & \\
\hline A3 & C/men's bathroom & 26.3 & not found & \\
\hline \multicolumn{5}{|c|}{ Sampling B } \\
\hline B1 & S/men's bathroom & 38.2 & $2.0 \times 10^{3}$ & $2-14$ \\
\hline B2 & S/women's bathroom & 29.1 & $1.4 \times 10^{3}$ & $2-14$ \\
\hline B3 & C/co-ed bathroom & 21.4 & $2.9 \times 10^{3}$ & $2-14$ \\
\hline B4 & S/men's bathroom & 19.3 & $9.8 \times 10^{2}$ & $2-14$ \\
\hline B5 & S/men's bathroom & 27.0 & $2.1 \times 10^{3}$ & $2-14$ \\
\hline B6 & S/women's bathroom & 37.9 & $4.4 \times 10^{3}$ & $2-14$ \\
\hline B7 & S/women's bathroom & 41.8 & $3.5 \times 10^{3}$ & $2-14$ \\
\hline B8 & S/disabled bathroom & 36.0 & $2.7 \times 10^{2}$ & $2-14$ \\
\hline B9 & S/women's bathroom & 30.2 & $2.4 \times 10^{3}$ & $2-14$ \\
\hline $\mathrm{B} 10$ & S/men's bathroom & 20.5 & $8.2 \times 10^{2}$ & $2-14$ \\
\hline B11 & S/men's bathroom & 16.1 & $4.0 \times 10^{0}$ & 1 \\
\hline $\mathrm{B} 12$ & S/women's bathroom & 20.0 & $7.0 \times 10^{3}$ & $2-14$ \\
\hline B13 & S/women's bathroom & 31.1 & $3.6 \times 10^{3}$ & $2-14$ \\
\hline B14 & S/men's bathroom & 22.3 & $1.8 \times 10^{3}$ & $2-14$ \\
\hline B15 & C/men's bathroom & 18.9 & not found & - \\
\hline B16 & C/men's bathroom & 27.8 & $5.6 \times 10^{2}$ & $2-14$ \\
\hline
\end{tabular}

Types of tap: S - sensory, C - classic. 
In one sample (A3 - a tap in the men's bathroom of a public utility building with an old water distribution system), no bacteria were found; in the remaining samples, Legionella colonies were identified (Fig. 1) in numbers exceeding admissible thresholds for public utility buildings $(100 \mathrm{cfu} / 100 \mathrm{~mL})$. In most samples (excluding A3, $\mathrm{B} 4, \mathrm{~B} 8, \mathrm{~B} 10, \mathrm{~B} 11, \mathrm{~B} 15, \mathrm{~B} 16)$, the parametric value from Directive (2000) was also exceeded.

The presence of Legionella rods in the A2 sample (a rarely used shower in a public building) is probably caused by the deposition of sludge and biofilm in a system that is not used.

De Filippis et al. (2018) opined that the presence of biofilm increases the survival and development of Legionella by protecting the bacteria from the effects of disinfection. In the case of sample A1 (men's bathroom in a public building, new water distribution system, infrared sensor tap), the problem may be insufficiently high water temperature. The automatic infrared sensor tap is activated for about 30 seconds after the infrared beam is interrupted, and the maximum instantaneous water temperature does not exceed $45^{\circ} \mathrm{C}$, so this system may be susceptible to bacterial colonisation. In the case of this water draw-off point, its frequent use does not protect the system against contamination in any way.
The second series of tests was conducted in 2019. This consisted of collecting water samples from taps in bathrooms which were connected to specific taps in different water risers. The taps were no-touch infrared sensor ones (13 samples) and conventional ones ( 3 samples). The results of Legionella bacteria counts are listed in Table 2 and Figure1.

When the results of the second series of tests were analysed, no Legionella bacilli were found in just one sample (B15), while in the B11 sample only 4 colony-forming units were detected. At the remaining draw-off points, the bacteria number detected were greater than the maximum threshold allowed by legal regulations.

In four cases (B4, B8, B10, and B16 points), the number of bacteria was in the range of $10^{2}-10^{3} \mathrm{cfu} / 100 \mathrm{~mL}$. The remaining twelve samples were found to contain $10^{3}-10^{4} \mathrm{cfu} / 100 \mathrm{~mL}$. The literature reports describe the occurrence of Legionella bacilli in tap water (Sabrià et al. 2001, Lesnik et al. 2016, Donohue 2021). The number of bacteria indicated is greater than the health-based targets for Legionella in piped water systems in selected European countries, which is set as a maximum $1000 \mathrm{cfu} / \mathrm{L}$ in France and Germany and $100 \mathrm{cfu} / \mathrm{L}$ in the Netherlands and United Kingdom (Bartram et al. 2007).

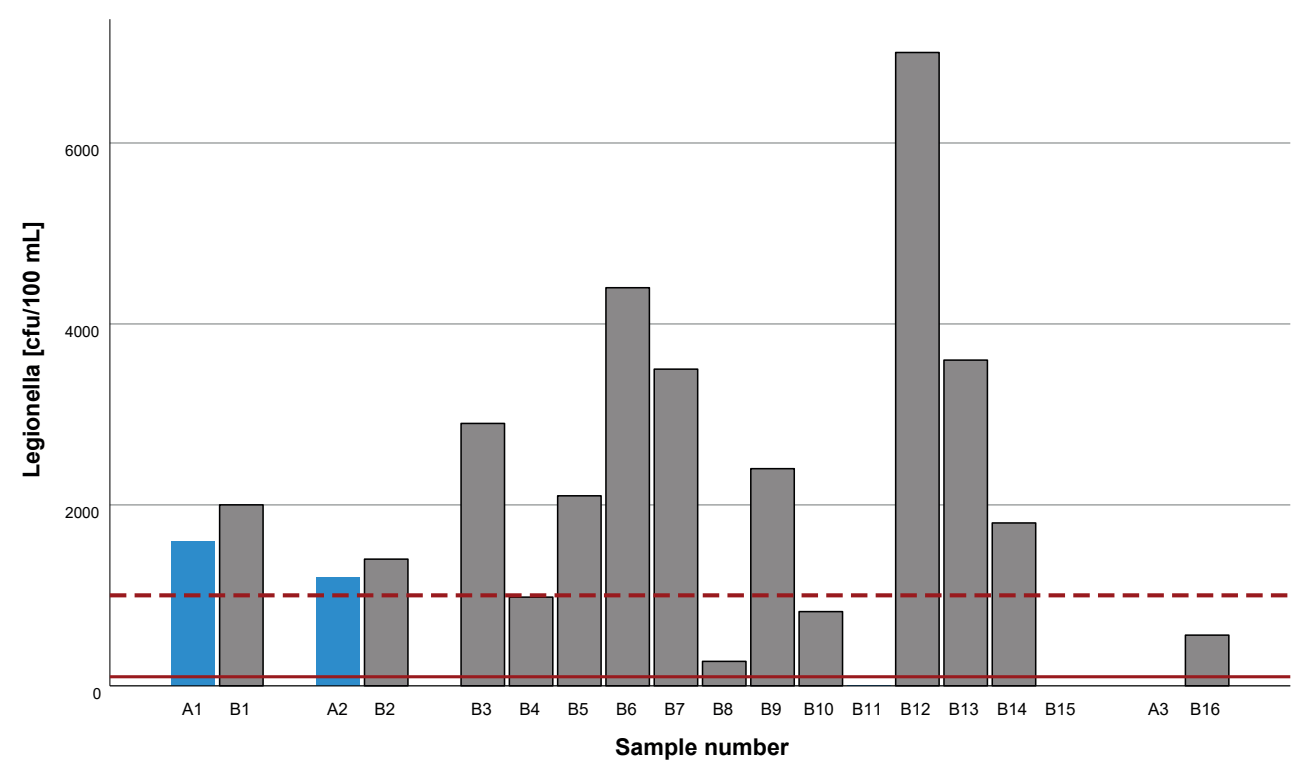

Fig. 1. Results of the tests. Red line indicates admissible thresholds for public utility buildings, the red dotted line indicates the parametric value from Directive (2020) 
A

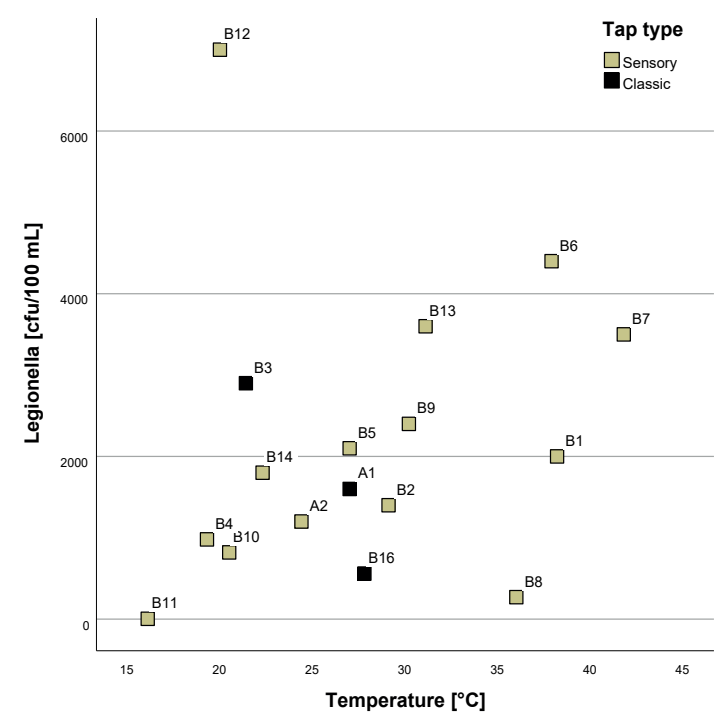

B

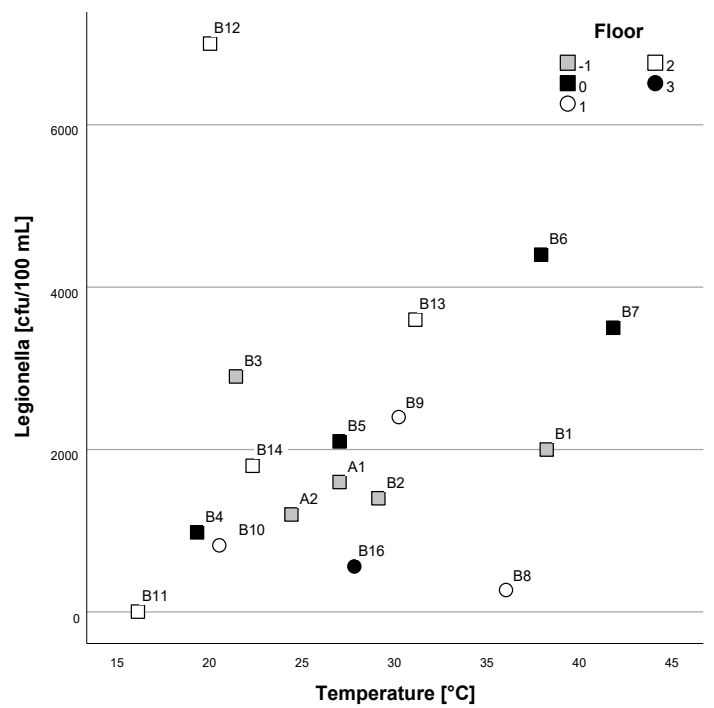

Fig. 2. Legionella bacteria in the samples analysed depending on water temperature. Data divided by the type of tap (A) and building floor $(B)$

In Figure 2, the results on scatter plots with breakdown by the type of tap (A) and building floors (B) are presented.

From the results obtained, it cannot be concluded that the presence of Legionella bacteria in water is related to the use of infrared sensor taps, since these bacteria were also found in conventional taps (connected to the same water supply riser). According to the tap manufacturers information, they equipped no-touch taps with thermal disinfection systems. This process consists of flushing the tap with hot water (about $70^{\circ} \mathrm{C}$ for 3-4 minutes), which destroys bacterial cells (Dur 2017), but the procedure is only effective if it is activated and the appropriate temperature of water in the water distribution system is ensured.

In Figure 3 the correlation between temperature and the number of bacteria in water risers is presented.

The method and frequency of using water from each riser have the greatest influence on the occurrence of Legionella in tap water, but it is not possible to give a straight answer on the correlation between each water riser and the number of Legionella bacteria.
The water temperature within risers changes between individual floors. In general, it decreases with height, although the opposite trend can sometimes be observed between floor 1 and floor 2. The smallest temperature difference between the floors was recorded in water riser 4 (women's bathrooms). In water risers 1, 4, and 5, an increase in Legionella bacteria count is observed as the water temperature rises, while in water riser 2 the trend is the opposite.

At the points which were sampled during both measurement series (A1 \& B1 and A3 \& B16), the number of bacteria increased over time, which may indicate favourable conditions for Legionella bacteria growth. The relatively constant number of colony units confirms that the system is not disinfected at regular intervals and suggests that Legionella has reached its maximum growth potential under the prevailing conditions (temperature, water distribution infrastructure, etc.).

Within both series, no Legionella bacteria were detected in the A3 and B15 samples, while in the second measurement series the number of Legionella bacteria at point B16 (the equivalent of A3) was already over $500 \mathrm{cfu} / 100 \mathrm{~mL}$, which indicates intensified bacterial growth. 
A

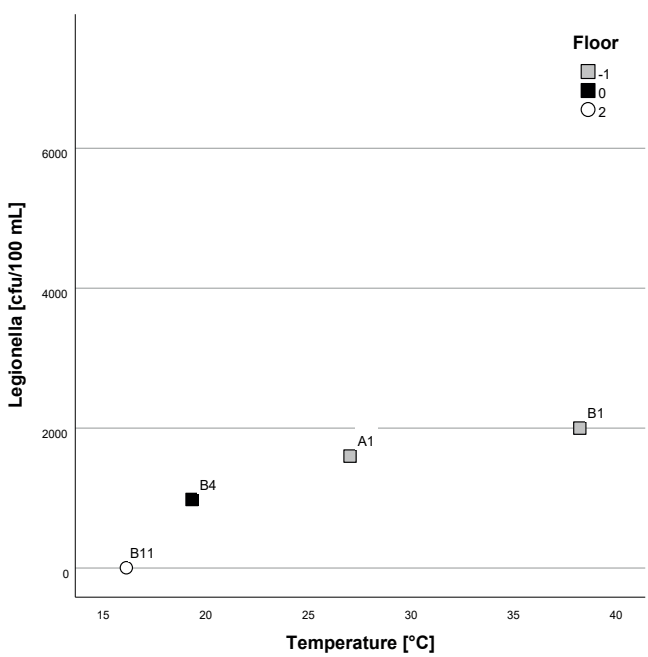

C

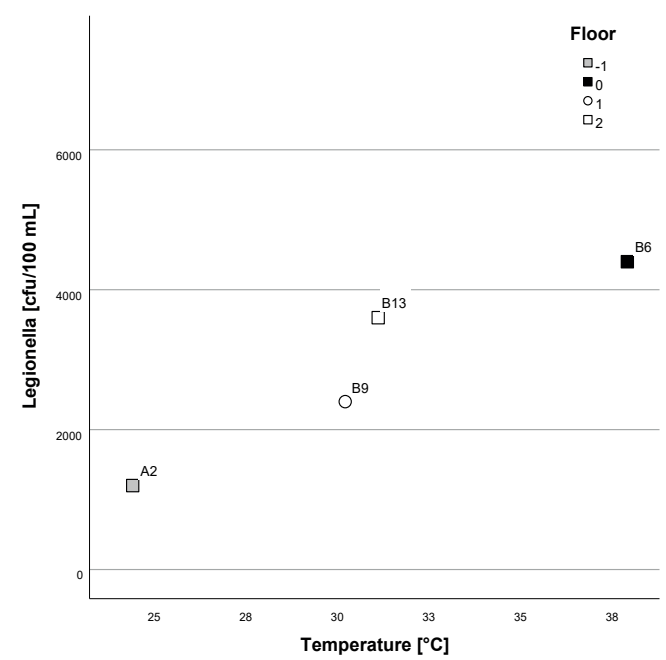

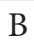

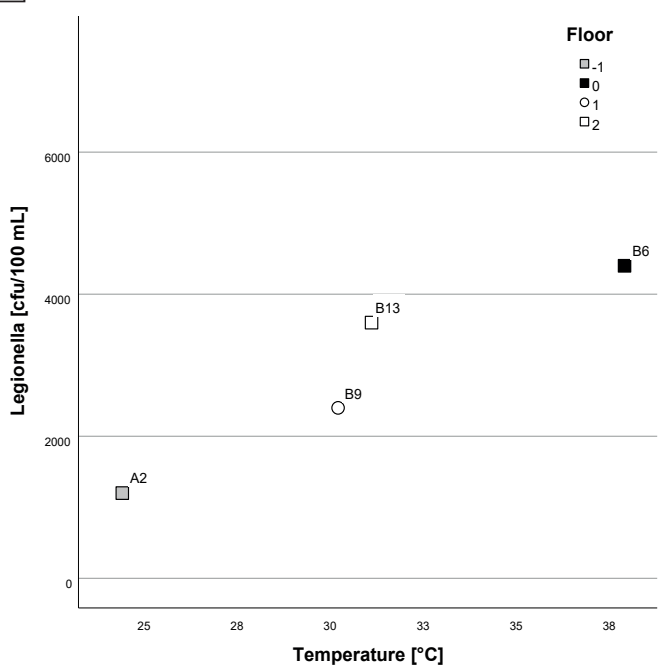

$\mathrm{D}$

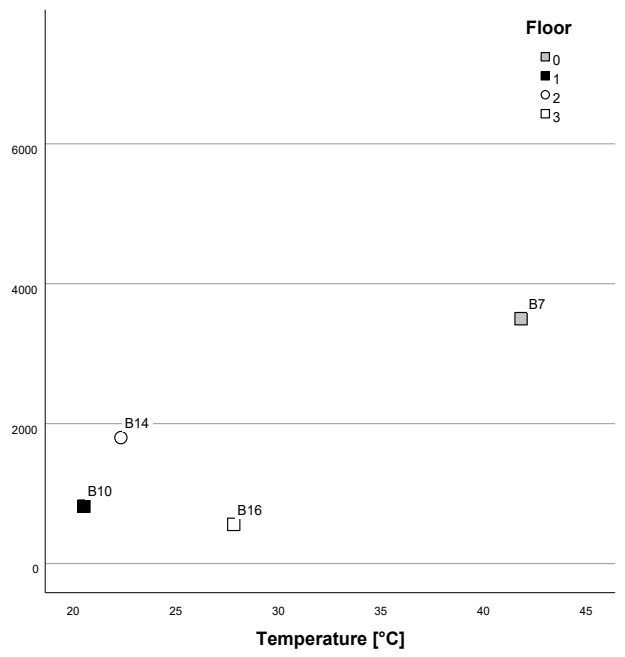

Fig. 3. The correlation between temperature and the number of bacteria in water risers: A) riser 1;B) riser 2; C) riser 4;D) riser 5 (Tab. 1)

The two draw-off points are located on different floors of a single building and are supplied by different water risers; they are used up to several hundred times per day. The fact that Legionella was identified at each of these points may suggest that the entire water distribution system in the building is contaminated with these bacteria.

In the samples in which Legionella bacteria were detected, serotyping was carried out to distinguish serogroups 1, 2-14 of Legionella pneumophila. The results are presented also in Table 2.

In the samples analysed, no morphological differences were observed with respect to the occurrence of specific serogroups. In 14 samples, Legionella pneumophila serogroups from 2 to14 were found, while the Legionella pneumophila serogroup 1 was only found in the P11b sample. The presence of a small amount of serogroup 1 within that tap may be caused by local external contamination of the tap itself. This result is somewhat dubious since the samples were collected from a single water distribution system riser and the rest of the water distribution system is free of this serogroup.

This serological group is very dangerous since it causes $67 \%$ of all disease cases (Fields et al. 2002). 
In each case where the Legionella bacteria family is present, disinfection must be carried out, since despite the fact that the risk is lower for other groups compared to serogroup 1, humans may still be infected, which may result in morbidity and even death. The building administrator was informed of the test results and disinfection was carried out.

\section{RISK ANALYSIS}

The presented research focused on Legionella occurrence in tap water from a public building. The risk assessment was carried out based on a semi-quantitative risk matrix approach (WHO 2009, 2017; European Standards 2013, Papadakis et al. 2018) and as a quantitative microbial risk assessment (QMRA) based on the method proposed by Armstrong \& Haas (2007a, 2007b), reviewed by Hamilton \& Haas (2016) and implemented by other scientists (Hines et al. 2014, Sharaby et al. 2019).

The main hazards identified in the analysed examples were:

1) Legionella occurrence in a water system,

2) inadequate water disinfection system,

3) too low water temperature,

4) low flow of water in the system,

5) water stagnation,

6) corrosion of water supply system,

7) long exposure to water contaminated with $L e$ gionella.

The highest likelihood (4) was estimated in a case of 1) and 3) identified hazards due to similar episodes in the past - Legionella was already found in the system and the water temperature is often much lower than $50^{\circ} \mathrm{C}$. A medium likelihood (3) was assessed in terms of water stagnation in the pipe system and probably corrosion of the water supply system because of the age of the installation (above 10 years), hard water in the system and the periods when water is not used due to the absence of users (e.g. holidays) and low flow of water in the system due to the use of water, usually only for hand washing. For other identified hazards, the frequency was set as 1 or 2 because of the lack of such episodes in the past, the systematic disinfection of water system compliant with the requirements and recommendations, and the short exposure (water used mostly for hand washing). The severity was set as 3 (medium) for all of the selected hazards except an example with long exposure to water contaminated with Legionella.

In Table 3, a risk assessment is presented.

The risk was found to be low in most of the analysed hazardous events which were identified. In two cases the risk was classified as medium. They were associated with the Legionella occurrence in water system and too low water temperature. Inadequate water temperature at the point of use poses a risk for human health (Boppe et al. 2016). Faucets and toilets have been already identified as a source of Legionella (Hines et al. 2014, Prussin et al. 2017). However, in total the risk should be considered as low because of the specific use of the analysed water. The highest risk for human infection occurs by aerosol inhalation and this is produced in very small amounts during hand washing.

Results of quantitative microbial risk assessment (QMRA) are presented in Table 4.

Table 3

Risk matrix

\begin{tabular}{|l|c|c|c|c|}
\hline \multicolumn{1}{|c|}{ Hazard } & $\begin{array}{c}\text { Likelihood } \\
\text { or frequency }\end{array}$ & Severity & Risk score & $\begin{array}{c}\text { Risk } \\
\text { rating }\end{array}$ \\
\hline Legionella occurrence in a water system & 4 & 3 & 12 & Medium \\
\hline Inadequate water disinfection system & 1 & 3 & 3 & Low \\
\hline Too low water temperature & 4 & 3 & 12 & Medium \\
\hline Low flow of water in the system & 3 & 3 & 9 & Low \\
\hline Water stagnation & 3 & 3 & 9 & Low \\
\hline Corrosion of water supply system & 3 & 3 & 9 & Low \\
\hline $\begin{array}{l}\text { Long exposure to water contaminated with } \\
\text { Legionella }\end{array}$ & 1 & 4 & 4 & Low \\
\hline
\end{tabular}


Table 4

Quantitative microbial risk assessment

\begin{tabular}{|c|c|c|c|c|}
\hline $\begin{array}{l}\text { Sample } \\
\text { no. }\end{array}$ & $\begin{array}{l}\text { Bacterial concen- } \\
\text { tration in inhalable } \\
\text { aerosol }\left[\mathrm{cfu} / \mathrm{m}^{3}\right] \\
C_{\text {air }}=C_{\text {water }} \times E F_{f / s}\end{array}$ & $\begin{array}{l}\text { Inhalation exposure dose } \\
\quad[\mathrm{cfu} / \text { week }] \\
\mathrm{IED}=C_{\text {air }} \times \mathrm{ED} \times \mathrm{RR} \times \mathrm{IR}\end{array}$ & $\begin{array}{l}\text { Predicted risk given } \\
\text { the weekly dose } \\
R_{w}(d)=1-e^{(-\gamma \mathrm{IED})}\end{array}$ & $\begin{array}{c}\text { Annual cumulative risk } \\
R_{A}(d)=1-\Pi_{w=1}^{n}\left[1-R_{w}(d)\right]\end{array}$ \\
\hline $\mathrm{A} 1$ & 8.96 & $9.15 \times 10^{-2}$ & $5.47 \times 10^{-3}$ & 0.25 \\
\hline A2 & 4.08 & $2.50 \times 1^{0-} 1$ & $1.49 \times 10^{-2}$ & 0.54 \\
\hline A3 & not found & \multicolumn{3}{|c|}{ not calculated } \\
\hline B1 & 11.20 & $1.14 \times 10^{-1}$ & $6.84 \times 10^{-3}$ & 0.30 \\
\hline B2 & 7.84 & $8.00 \times 10^{-2}$ & $4.79 \times 10^{-3}$ & 0.22 \\
\hline B3 & 16.24 & $1.66 \times 10^{-1}$ & $9.90 \times 10^{-3}$ & 0.40 \\
\hline B4 & 5.49 & $5.60 \times 10^{-2}$ & $3.36 \times 10^{-3}$ & 0.26 \\
\hline B5 & 11.76 & $1.20 \times 10^{-1}$ & $7.18 \times 10^{-3}$ & 0.31 \\
\hline B6 & 24.64 & $2.52 \times 10^{-1}$ & $1.50 \times 10^{-2}$ & 0.54 \\
\hline B7 & 19.60 & $2.00 \times 10^{-1}$ & $1.19 \times 10^{-2}$ & 0.46 \\
\hline B8 & 1.51 & $1.54 \times 10^{-2}$ & $9.26 \times 10^{-4}$ & 0.05 \\
\hline B9 & 13.44 & $1.37 \times 10^{-1}$ & $8.20 \times 10^{-3}$ & 0.35 \\
\hline B10 & 4.59 & $4.69 \times 10^{-2}$ & $2.81 \times 10^{-3}$ & 0.14 \\
\hline B11 & 0.02 & $2.29 \times 10^{-4}$ & $1.37 \times 10^{-5}$ & 0.001 \\
\hline $\mathrm{B} 12$ & 39.20 & $4.00 \times 10^{-1}$ & $2.37 \times 10^{-2}$ & 0.71 \\
\hline B13 & 20.16 & $2.06 \times 10^{-1}$ & $1.23 \times 10^{-2}$ & 0.47 \\
\hline B14 & 10.08 & $1.03 \times 10^{-1}$ & $6.15 \times 10^{-3}$ & 0.27 \\
\hline B15 & not found & \multicolumn{3}{|c|}{ not calculated } \\
\hline B16 & 3.14 & $3.20 \times 10^{-2}$ & $1.92 \times 10^{-3}$ & 0.10 \\
\hline
\end{tabular}

Water to air emission factor was set as $5.6 \times 10^{-4} \mathrm{~L} / \mathrm{m}^{3}$ for faucets $\left(\mathrm{EF}_{f}\right)$ and $3.4 \times 10^{-4} \mathrm{~L} / \mathrm{m}^{3}$ for showers $\left(\mathrm{EF}_{s}\right)$, weekly exposure duration (ED) was estimated as $7 \mathrm{~min}$ for the shower (1 shower a week) and 70 seconds for faucets (2 times hand washing for about 7 seconds during 5 days) (Hines et al. 2014, Sharaby et al. 2019). The inhalation rate was set as $1.05 \mathrm{~m}^{3} / \mathrm{h}$ using specification of US EPA (2011). The fractional retention rate was estimated as 0.5 (Borchgrevink et al. 2013, Sharaby et al. 2019). Model parameter for Legionella infection risk $(\gamma)$ was set as $0.061 / \mathrm{cfu}$.

The weekly inhalation exposure doses calculated based on the results obtained vary from $2.29 \times 10^{-4}$ (B11) to $4.00 \times 10^{-1} \mathrm{cfu} /$ week (B12). Appropriately, the lowest calculated annual cumulative risk is equal to 0.001 and the highest is 0.71 . The mean annual cumulative risk was evaluated as 0.30 . Even so, no case of Legionellosis was found in the tested public building. This may suggest that the risk found is overestimated due to the uncertainty of such evaluations and the degree of variability of Legionella in tap water during any given year (Lesnik et al. 2013, Hamilton et al. 2019).
The presented research proves that the number of bacteria in the same tap changed during the two conducted campaigns. A number of researchers have highlighted that the air-water partitioning coefficient is a major source of uncertainty in the Legionella QMRA process (Armstrong \& Haas 2007a, 2007b, Schoen \& Ashbolt 2011, Buse \& Ashbolt 2012).

\section{CONCLUSIONS}

The presence of Legionella in public buildings is an immense problem. In such buildings, the responsibility for carrying out proper disinfection is divided between multiple functions and inspections are not carried out sufficiently frequently - the absence of a direct owner and user makes such prevention and disinfection measures rare or non-existent (Springston \& Yocavitch 2017). According to estimates from the Polish literature, the prevalence of water contamination with Legionella in multi-apartment residential buildings in Poland may reach up to $65 \%$. In Great Britain, it is $15 \%$, while in Finland it is only 8\% (Jamiołkowski 2020). 
The contamination of water distribution systems may either be local and only involve some fittings (e.g., gasket or shower head) or it may extend to the entire water supply and distribution network, which is more likely in the case discussed here. At central points of large networks, there are often places where bacteria find their ecological niches in which they multiply and from which they are subsequently washed away (States et al. 1985). The metal parts of the pipe components and associated corrosion products can be also an important factor in the survival and growth of $L$. pneumophila in water systems (States et al. 1985, Martin et al. 2020).

When analysing the results of the tests performed, it was found that apart from favourable temperature conditions, there is no other factor that results in the increased occurrence of Legionella bacteria in any specific part of the water distribution system. Moreover, Rhoads et al. (2015) assessed temperature as a critical factor for Legionella development. Bacteria counts in taps and showers were similar and did not depend on the frequency of their use or the floor on which the sampling point was located.

Legionella bacteria do not pose a threat to users of hot water storage tanks heated by coal-fired boilers, since these tanks can be heated to temperatures of $70^{\circ} \mathrm{C}$ (Jamiołkowski 2020). Users of the district heating network do not have this opportunity, however, and thus this problem also concerns public buildings.

Proposals for a comprehensive solution to the Legionella problem (for both private users and public buildings) should be included in amended regulations concerning the quality of drinking water and water at swimming pools as well as the Construction Law (Główny Inspektorat Sanitarny 2014, Rozporządzenie 2015b).

With aging and increasingly immunocompromised populations, a better understanding of opportunistic pathogens including Legionella in household water systems will become more important (Borella et al. 2005, Collinset al. 2017) and the same is true for public buildings.

The results of health risk analysis indicate that the singular results coming from one grab sample can give an incorrect estimation of exposure and the likelihood of Legionellosis.

\section{REFERENCES}

Amemura-Maekawa J., Kura F., Helbig J.H., Chang B., Kaneko A., Watanabe Y. et al., 2010. Characterization of Legionella pneumophila isolates from patients in Japan according to serogroups, monoclonal antibody subgroups and sequence types. Journal of Medical Microbiology, 59, 653-659.

Amemura-Maekawa J., Kura F., Chida K., Ohya H., Kanatani J., Isobe J. et al., 2018. Legionella pneumophila and other Legionella species isolated from Legionellosis $\mathrm{Pa}-$ tients in Japan between 2008 and 2016. Applied and Environmental Microbiology, 84(18), 721-818. https://doi. org/10.1128/AEM.00721-18.

Armstrong T.W. \& Haas C.N., 2007a. A quantitative microbial risk assessment model for Legionnaires' disease: animal model selection and dose-response modeling. Risk Analysis: An International Journal, 27(6), 1581-1596. https://doi.org/10.1111/j.1539-6924.2007.00990.x.

Armstrong T.W. \& Haas C.N., 2007b. Quantitative microbial risk assessment model for Legionnaires' disease: assessment of human exposures for selected spa outbreaks. Journal of Occupational and Environmental Hygiene, 4(8), 634-646. https://doi.org/10.1080/15459620701487539.

Bartram J., Chartier Y., Lee J.V., Pond K. \& Surman-Lee S. (eds.), 2007. Legionella and the Prevention of Legionellosis. World Health Organization.

Benhammou S., De La Torre A., Oleo F., Rivas A. \& Lorenzo M., 2012. Control of legionella. [in:] Maraver F. \& Karagülle M.Z. (eds.), Medical Hydrology and Balneology: Environmental Aspects, Balnea. Serie de Monografias, 6, Universidad Complutense, Madrid, 340-341.

Boppe I., Bédard E., Taillandier C., Lecellier D., Nantel-Gauvin M.A., Villion M., Laferrière C. \& Prévost M., 2016. Investigative approach to improve hot water system hydraulics through temperature monitoring to reduce building environmental quality hazard associated to Legionella. Building and Environment, 108, 230-239. https://doi.org/10.1016/j.buildenv.2016.08.038.

Borchgrevink C.P., Cha J. \& Kim S., 2013. Hand washing practices in a college town environment. Journal of Environmental Health, 75(8), 18-25.

Borella P., Montagna M.T., Stampi S., Stancanelli G., Romano-Spica V., Triassi M., Marchesi I., Bargellini A., Tato D., Napoli C., Zanetti F., Leoni E., Moro M., Scaltriti S., Ribera D'Alcala G., Santarpia R. \& Boccia S., 2005. Legionella contamination in hot water of Italian hotels. Applied and Environmental Microbiology, 71, 5805-5813. https://doi.org/10.1128/AEM.71.10.5805-5813.2005.

Buse H.Y. \& Ashbolt N.J., 2012. Counting Legionella cells within single amoeba host cells. Applied and Environmental Microbiology, 78(6), 2070-2072. https://doi. org/10.1128/AEM.71.7.4086-4096.2005.

Collins S., Stevenson D., Bennett A. \& Walker J., 2017. Occurrence of Legionella in UK household showers.International Journal of Hygiene and Environmental Health, 220, 401-406. https://doi.org/10.1016/j.ijheh.2016.12.001.

De Filippis P., Mozzetti C., Messina A. \& D’Alò G.L., 2018. Prevalence of Legionella in retirement homes and group homes water distribution systems. Science of the Total Environment, 643, 715-724. https://doi.org/10.1016/j.scitotenv.2018.06.216. 
Delgado-Viscogliosi P., Simonart T., Parent V., Marchand G. Dobbelaere M., Pierlot E., Pierzo V., Menard-Szczebara F., Gaudard-Ferveur E., Delabre K. \& Delattre J.M., 2005. Rapid method for enumeration of viable Legionella pneumophila and other Legionella spp. in water. $A p$ plied and Environmental Microbiology, 71, 4086-4096. https://doi.org/10.1128/AEM.71.7.4086-4096.2005.

Directive, 2020. Directive (EU) 2020/2184 of the European Parliament and of the Council of 16 December 2020 on the quality of water intended for human consumption (recast). OJ L 435, 23.12.2020. http://data.europa.eu/eli/ dir/2020/2184/oj [access: 21.01.2021].

Donohue M.J., 2021. Quantification of Legionella pneumophila by qPCR and culture in tap water with different concentrations of residual disinfectants and heterotrophic bacteria. Science of the Total Environment, 774, 145142. https://doi.org/10.1016/j.scitotenv.2021.145142.

Dur N., 2017. Bateria bezdotykowa - co to takiego i jak działa? Łazienkaplus.pl. https://www.lazienkaplus.pl/pl/blog/ bateria-bezdotykowa-co-to-takiego-i-jak-dziala-180 [access: 1.09.2020].

ECDC, 2017. Legionnaires' disease in Europe, 2015. European Centre for Disease Prevention and Control, Stockholm.

ESGLI, 2017. European technical guidelines for the prevention, control and investigation of infections caused by Legionella species. European Society of Clinical Microbiology and Infectious Diseases. https://www.escmid.org/fileadmin/ src/media/PDFs/3Research_Projects/ESGLI/ESGLI_European_Technical_Guidelines_for_the_Prevention Control_and_Investigation_of_Infections_Caused_by_ Legionella_species_June_2017.pdf [access: 1.09.2020].

European Standards, 2013. Security of drinking water supply-Guidelines for risk and crisis management - Part 2: Risk management, DIN EN 15975-2. https://www. en-standard.eu/csn-en-15975-2-securityof-drinkingwater-supply-guidelines-for-risk-and-crisis-management-part-2-risk-management/ [access: 24.03.2020].

Fields B., Benson R.F. \& Besser R.E., 2002. Legionella and legionnaires' disease: 25 years of investigation. Clinical Microbiology Reviews, 15, 3, 506-526. https://doi. org/10.1128/CMR.15.3.506-526.2002.

Garret L., 1994. The Coming Plague: Newly Emerging Diseases in a World Out of Balance. Farrar, Straus and Giroux, New York.

Główny Inspektorat Sanitarny, 2014. Wytyczne Głównego Inspektoratu Sanitarnego w sprawie wymagań jakości wody oraz warunków sanitarno-higienicznych na plywalniach [Guidelines of the State Sanitary Inspectorate on the requirements of water quality and sanitary-hygienic conditions in swimming pools]. Państwowa Inspekcja Sanitarna, Warszawa.https://www.gov.pl/attachment/152b6e52-3e7548e8-8c29-f53177819700 [access: 24.03.2020].

Hamilton K.A. \& Haas C.N., 2016. Critical review of mathematical approaches for quantitative microbial risk assessment (QMRA) of Legionella in engineered water systems: research gaps and a new framework. Environmental Science: Water Research and Technology, 2(4), 599-613. https://doi.org/10.1039/C6EW00023A.

Hamilton K.A., Hamilton M.T., Johnson W., Jjemba P., Bukhari Z., LeChevallier M., Haas Ch.N. \& Gurian P.L., 2019. Risk-Based Critical Concentrations of Legionella pneumophila for Indoor Residential Water Uses. Environmental Science and Technology, 53(8), 4528-4541. https://doi.org/10.1021/acs.est.8b03000.
Helbig J.H., Bernander S., Castellani Pastoris M., Etienne J., Gaia V., Lauwers S. et al., 2002. Pan-European study on culture-proven Legionnaires's disease: distribution of Legionella pneumophilaserogroups and monoclonal subgroups. European Journal of Clinical Microbiology \& Infectious Diseases, 21(10), 710-716.

Hines S.A., Chappie D.J., Lordo R.A., Miller B.D., Janke R.J., Lindquist H.A., Fox K.R., Ernst H.S. \& Taft S.C., 2014. Assessment of relative potential for Legionella species or surrogates inhalation exposure from common water uses. Water Research, 56, 203-213. https://doi. org/10.1016/j.watres.2014.02.013.

Huang L., Boyd D., Amyot W., Hempstead A.D., Luo Z., O'Connor T.J., Chen C., Machner M., Montminy T. \& Isberg R.R., 2011. The E Block motif is associated with Legionella pneumophila translocated substrates. Cellular Microbiology,13, 227-245. https://doi.org/10.1111/j.14625822.2010.01531.x.

ISO, 2017. Water quality - Enumeration of Legionella. ISO standard no. 11731:2017.

Jamiołkowski A., 2020: Zwalczanie bakterii Legionella w instalacji domowej. BudujemyDom.pl. https://www.budujemydom.pl/woda-i-kanalizacja/18352-zwalczanie-bakterii-legionella-w-instalacji-domowej [access: 1.09.2020].

KmiecikE., Wątor K., Mika A., Chochorek A. \& Kołodziej M., 2017. Bacterias from Legionella group in the hot water installations in public buildings. [w:] SGEM 2017: international multidisciplinary scientific geoconference: water resources forest, marine and ocean ecosystems. Conference proceedings. Vol. 17 iss. 31, Hydrology and water resources marine and ocean ecosystems, STEF92 Technology Ltd., Sofia, 67-72.

Lesnik R., Brettar I. \& Höfle M.G., 2016. Legionella species diversity and dynamics from surface reservoir to tap water: from cold adaptation to thermophily. ISME Journal, 10(5), 1064. https://doi.org/10.1038/ismej.2015.199.

Liguori G., Di Onofio V., Galle F., Liguori R., Nastro R.A. \& Guida M., 2014. Occurrence of Legionella spp. in thermal environments: Virulence factors and biofilm in isolates from spa. Microchemical Journal, 112, 109-112. https://doi.org/10.1016/j.microc.2013.09.023.

Martin R.L., Strom O.R., Pruden A. \& Edwards M.A., 2020. Interactive Effects of Copper Pipe, Stagnation, Corrosion Control, and Disinfectant Residual Influenced Reduction of Legionella pneumophila during Simulations of the Flint Water Crisis. Pathogens, 9, 730. https://doi. org/10.3390/pathogens9090730.

Mika A., Kmiecik E., Krawiec A., Wątor K., Zamfir M. \& Chochorek A., 2019. Legionella pneumophila in Thermal Spa-Methodological Aspects of Sampling and Analysis. Geomicrobiology Journal, 36(5), 460-467. https:// doi.org/10.1080/01490451.2019.1571127.

Miyashita N., Higa F., Aoki Y., Kikuchi T., Seki M., Tateda K., Maki N., Uchino K., Ogasawara K., Kiyota H. \& Watanabe A., 2020. Distribution of Legionella species and serogroups in patients with culture-confirmed Legionella pneumonia. Journal of Infection and Chemotherapy, 26(5), 411-417. https://doi.org/10.1016/j.jiac.2019.12.016.

Papadakis A., Chochlakis D., Sandalakis V., Keramarou M., Tselentis Y. \& Psaroulaki A., 2018. Legionella spp. risk assessment in recreational and garden areas of hotels. International Journal of Environmental Research and Public Health, 15(4), 598. https://doi.org/10.3390/ ijerph15040598. 
Prussin II A.J., Schwake D.O. \& Marr L.C., 2017. Ten questions concerning the aerosolization and transmission of Legionella in the built environment. Building and Environment, 123, 684-695. https://doi.org/10.1016/j.buildenv.2017.06.024.

Rafiee M., Jahangiri-rad M., Hajjaran H., Mesdaghinia A. \& Hajaghazadeh M., 2014. Detection and identification of Legionella species in hospital water supplies through Polymerase Chain Reaction (16S rRNA). Journal of Environmental Health Science \& Engineering, 12(1), 83. https://doi.org/10.1186/2052-336X-12-83.

Rasilainen T., Breitenstein A., Tilsala-Timisjärvi A., Kusnetsov J., Salkinoja-Salonen M. \& Neubauer P., 2005. Novel detection method for pathogenic Legionella in water systems. [in:] Jalkanen A. \& Nygren P. (eds.), Sustainable use of renewable natural resources: from principles to practices, Department of Forest Ecology, University of Helsinki, 197-207.

Rhoads W.J., Ji P., Pruden A. \& Edwards M.A., 2015. Water heater temperature set pointand water use patterns influence Legionella pneumophila and associated microorganisms at the tap. Microbiome, 3, 67. http://dx.doi. org/10.1186/s40168-015-0134-1.

Rozporządzenie, 2002. Rozporządzenie Ministra Infrastruktury z dnia 12 kwietnia 2002 r. w sprawie warunków technicznych, jakim powinny odpowiadać budynki i ich usytuowanie [Regulation of the Minister of Infrastructure on the technical conditions to be met by buildings and their location]. Dz.U. $2002 \mathrm{nr} 75$, poz. 690.

Rozporządzenie, 2005. Rozporzadzenie Ministra Zdrowia $z$ dnia 22 kwietnia 2005 r. w sprawie szkodliwych czynników biologicznych dla zdrowia w środowisku pracy oraz ochrony zdrowia pracowników zawodowo narażonych na te czynniki [Regulation of the Minister of Health on biological agents which are harmful to health in the work environment and on the health protection of employees professionally exposed to these agents]. Dz.U. 2005 nr 81, poz. 716.

Rozporządzenie, 2015a. Rozporządzenie Ministra Zdrowia $z$ dnia 13 listopada 2015 r. w sprawie jakości wody przeznaczonej do spożycia przez ludzi [Regulation of the Minister of Health on the quality of water intended for human consumption]. Dz.U. 2015, poz. 1989.

Rozporządzenie, 2015b. Rozporzadzenie Ministra Zdrowia $z$ dnia 9 listopada 2015 r. w sprawie wymagań, jakim powinna odpowiadać woda na plywalniach [Regulation of the Minister of Health on the requirements to be met by water in swimming pools]. Dz.U. 2015 poz. 2016.

Sabrià M., García-Núñez M., Pedro-Botet M.L., Sopena N., Gimeno J.M., Reynaga E., Morera J. \& Rey-Joly C., 2001. Presence and chromosomal subtyping of Legionella species in potable water systems in 20 hospitals of Catalonia, Spain. Infection Control \& Hospital Epidemiology, 22(11), 673-676. https://doi.org/10.1017/S0195941700072623.

Schoen M.E. \& Ashbolt N.J., 2011. An in-premise model for Legionella exposure during showering events. Water Research, 45(18), 5826-5836. https://doi.org/10.1016/ j.watres.2011.08.031.

Sharaby Y., Rodríguez-Martínez S., Höfle M.G., Brettar I. \& Halpern M., 2019. Quantitative microbial risk assessment of Legionella pneumophila in a drinking water supply system in Israel. Science of the Total Environment, 671, 404-410. https://doi.org/10.1016/j.scitotenv.2019.03.287.

Springston J.P. \& Yocavitch L., 2017. Existence and control of Legionella bacteria in building water systems: A review. Journal of Occupational and Environmental Hygiene, 14(2), 124-134. https://doi.org/10.1080/15459624. 2016.1229481.

States S.J., Conley L.F., Ceraso M., Stephenson T.E., Wolford R.S., Wadowsky R.M., McNamara A.M. \& Yee R.B., 1985. Effects of metals on Legionella pneumophila growth in drinking water plumbing systems. Applied and Environmental Microbiology, 50, 1149-1154.

Stypułkowska-Misiurewicz H. \& Czerwiński M., 2016. Legioneloza w Polsce w 2014 roku [Legionellosis in Poland in 2014]. Przeglą Epidemiologiczny, 70(2), 203-207.

US EPA, 1999. Legionella: Human Health Criteria Document. EPA-822-R-99-001, US Environmental Protection Agency, Washington, DC.

US EPA, 2011. Exposure Factors Handbook 2011 Edition (Final Report). EPA/600/R-09/052F, US Environmental Protection Agency, Washington, DC.

Walczak M., Kletkiewicz H. \& Burkowska A., 2013a. Occurrence of Legionella pneumophila in lakes serving as a cooling system of a power plant. Environmental Science: Processes \& Impacts, 15, 2273. https://doi. org/10.1039/C3EM00452J.

Walczak M., Krawiec A. \& Lalke-Porczyk E., 2013b. Legionella pneumophila bacteria in a thermal saline bath. $A n$ nals of Agricultural and Environmental Medicine, 20, 4, 649-652.

Walczak M., Burkowska-But A., Świontek-Brzezinska M. \& Krawiec A., 2016. Distribution of Legionella pneumophila in Thermal Pools. CLEAN Soil Air Water, 44(5), 532537. https://doi.org/10.1002/clen.201400926.

Walser S.M., Gerstner D.G., Brenner B., Höller C., Liebl B. \& Herr C.E.W., 2014. Assessing the environmental health relevance of cooling towers - A systematic review of legionellosis outbreaks. International Journal of Hygiene and Environmental Health, 217, 145-154. https://doi. org/10.1016/j.ijheh.2013.08.002.

WHO, 2009. Water Safety Plan Manual (WSP Manual). https://www.who.int/publications/i/item/9789241562638/ [access:24.03.2020].

WHO, 2017. WHO methods and data sources for global burden of disease estimates 2000-2015. Department of Information, Evidence and Research WHO, Geneva. https:// www.who.int/healthinfo/global_burden_disease/GlobalDALYmethods_2000_2015.pdf [access: 24.03.2020].

Wiedenmann A., Langhammer W. \& Botzenhart K., 2001. A case report of false negative Legionella test results in a chlorinated public hot water distribution system due to the lack of sodium thiosulfate in sampling bottles. International Journal of Hygiene and Environmental Health, 204(4), 245-249. https://doi.org/10.1078/1438-4639-00101.

Yu V.L., Plouffe J.F., Pastoris M.C., Stout J.E., Schousboe M., Widmer A., Summersgill J., File T., Heath C.M., Paterson D.L. \& Chereshsky A., 2002. Distribution of Legionella species and serogroups isolated by culture in patients with sporadic community-acquired legionellosis: an international collaborative survey. Journal of Infectious Diseases, 186, 127-128. 